\title{
Creation of a Mobile App for the Promotion of Social Skills as a Way out of Cyberbullyng Situations for Intercultural Reasons
}

\author{
Christian Fernández-Leyva, José Manuel Ortiz-Marcos and María Tomé-Fernández \\ University of Granada/ Department of Research Methods and Diagnosis in Education
}

\begin{abstract}
In this study, the cyberbullying situation promoted by the intolerance towards cultural and religious diversity suffered by both native and immigrant students, at present, of the different centers of Compulsory Secondary Education is analyzed. Therefore, the objective of this work is to adapt two instruments to evaluate the opinions of students regarding the content of what this mobile App should contain. To complete these two questionnaires, 284 students were taken as a sample to develop the research, all of Compulsory Secondary Institutes and University of Spain. These questionnaires consist of two "yes" or "no" answer options structured in 29 items and 18 items, which were extracted from relevant scales on the subject to be investigated. Once the data of the participants has been obtained and the issues that they have considered most relevant to include in the mobile application have been selected, the development and design of a new mobile App creation will be carried out, with the aim of helping or guiding People who suffer these types of intentional attacks.
\end{abstract}

Keywords: Cultural diversity; Education; Intolerance; Opinions, Questionnaires. 


\section{EDUCATION}

\section{Cultural and religious cyberbullying}

Bullying in recent decades has been the essence of multiple studies, becoming a primary theme in the scientific world (González \& Prendes, 2018). However, today another current problem should be indicated, such as Information and Communication Technologies (ICT), which have led to what is known as "cyberbullying" (Cardozo, Dubini, \& Lorenzino, 2017). To this phenomenon, a new problem has arisen, that is, rejection towards the culturally different, being a social problem whose prevalence and stability, regardless of the country or culture, has increased considerably in recent years among the youngest (Aboujaoude, Savage, Starcevic, \& Salame, 2015). This type of cultural harassment has a serious socio-emotional impact on the victim, who can be affected, among others, the development of his personality, self-esteem, social skills and conflict resolution capacity (Zych, Ortega-Ruiz, \& Marin-Lopez, 2016).

The use of technologies has had a growth in Spanish households of $81.9 \%$ having access to the Network in 2016, this percentage has been rising now up to $98 \%$ (National Statistics Institute, 2019). Being today the main type of Internet connection via mobile, where $97.4 \%$ of households have at least one (Santana-Vega, Gómez-Muñoz, \& Feliciano-García, 2019). The use of technological devices and the place they occupy in our system generates new forms of relationship between peer groups (Torrecillas-Lacave, Vazquez-Barrio, \& Monteagudo-Barandalla, 2017).

In a culture or society, depending on how you consider the acceptance and adoption of technology, culture influences the thinking and attitudes of individuals, the level of innovation and the willingness to accept uncertainties, and also determines what the norms are how to act in a given situation (Rosen, Carrier, Miller, Rokkum, Ruiz, 2016). Given the great influence that culture influences the way of thinking of a society, it would be a logical assumption that culture can influence how people perceive technology (Thomée, 2018). Various investigations show the inadequate relationship between the participation of adolescents in social networks on the Internet and the generated social capital, leading to cyberbullying, spatially suffered by minority social groups or belonging to other ethnic cultures (Ellison \& Vitak, 2015; Lambert, 2016; Sádaba \& Vidales, 2015).

All these studies support this situation, however, adequate methods to measure this resource of an intangible nature must still be developed, so that the influence that communication mediated by technologies, and in particular by mobile, has on social relations can be understood of the youngest (Vidales-Bolaños \& Sádaba-Chalezquer, 2017). Given all these facts, there are few mobile App projects that address and are focused with the objective of acting against cultural or religious harassment (Boduszek, Debowska, Jonesa, Ma, Smith, Willmott, Jemmotte, Da Breof, \& Kirkmana, 2019). In addition, there is generally a lack of serious Apps that address the different forms of cultural harassment in both Western and non-Western countries and, in which few include in society (Nielsen, Haun, Kärtner, \& Legare, 2017). 


\section{EDUCATION}

As indicated by Larrañaga, Navarro, Yubero (2018) due to the events that are taking place in this area and given the relevance of the topic, there is a lack of research that jointly studies cyberbullying for cultural reasons, such as the creation of mobile applications that can act against this type of phenomena. Therefore, it is necessary to create a App as a means of intervention that could offer protection conditions, through peer and peer membership groups available and attentive to support them when certain young people suffer from this type of digital harassment (Della- Cioppa, O'Neil, \& Craig, 2015).

\section{Need for an App}

Due to cyberbullying or cyberbullying (Hosseinmardi, Rafiq, Han, Lv, \& Mishra, 2016), it is considered necessary to create a mobile App, to help in the attempt to end these attacks. According to Tabuenca, Sánchez-Peña and Cuetos-Revuelta (2019), it would be interesting to explore experiences with games and mobile applications to raise awareness, and also report cases of cyberbullying.

As other authors have already mentioned, there is the creation of video games to achieve this task, as is the case of Jesse, a prosocial videogame that aims to increase the capacity for emotional and cognitive response to victims of gender violence in the domestic context (Smith, Ma, Jones \& Unver, 2017). In addition, videogames are based on the experience of the players using narrative and audiovisual content, adding rules and objectives to regulate their behavior, so prosocial videogames with an appropriate design can be used as teaching tools, to improve moral reasoning, prosocial cognitions, useful behavior, positive effect, as well as to encourage empathy and improve social skills (Catalano, Luccini \& Mortara, 2014).

In this sense, in some fields the use of applications to improve skills such as those related to job interviews have already been introduced (Cartwright, 2017; Turner, Landmann \& Kirkland, 2019). Another tool created has been an application to help evaluate and transmit nonverbal behaviors called NOCOA (Tanaka, Sakti, Neubig, Toda \& Nakamura, 2015). And, although to contribute to the improvement of social skills in general, the "Let's be social" App (Baton, Crosland \& Haynes, 2019) was created, there is no record of the existence of any App that encourages the use of skills social oriented to avoid the suffering of cyberbullying.

\section{Improvement of social skills}

In the same way that it has been tried to make prosocial videogames, and Apps to assess the skills in job interviews or the transmission of nonverbal behaviors, it is considered necessary, for this study, the creation of a mobile App to seek the improvement of skills users' social avoidance, so that they suffer cyberbullying or cyberbullying. Based on the App "Let's be social" (Baton, Crosland \& Haynes, 2019), an App will be developed to prevent cyberbullying by improving social skills. Social skills are defined by GilMadrona, Gutiérrez and Madrid (2012) as behaviors through which people are able to express ideas, opinions, feelings and affection for others, such as maintaining and 


\section{EDUCATION}

improving interpersonal relationships, reinforcing situations social, so they consider that their training increases the frequency of assertive behaviors and communication skills of group interaction, such as: giving and requesting help, giving and receiving explanations or asking and answering questions.

These authors also point out that social skills are related to a good psychological adjustment, a reduction of social stress, the achievement of a broader social circle, having good self-esteem, having fewer conflicts with others, possessing self-control, tranquility, having a positive perception from others and self-affirmation. According to Fernández, Mena \& Riviere (2010), social skills should be included in educational curricula to promote the cognitive development of students, through collaborative work, which would provide ideal situations to promote empathy and interpersonal relationships, strengthening emotional bonds between same.

Due to the need to strengthen these emotional bonds and collaborative work, there has been an increase in connectivity among students, thinking that it offers social benefits, but beyond those benefits there are also certain risks, which can cause what is called as cyber bullying or cyberbullying (Fernández-Montalvo, Peñalva \& Irazabal, 2015).

One of the ways to end cyberbullying is through the improvement of social skills, where English, Benavides, Redondo, García-Fernández, Ruiz-Esteban and Estévez (2009) expose the increase they have suffered in recent years, the studies on pro-social behaviors in Compulsory Secondary Education, due to its relevance in establishing positive interpersonal relationships and improving personal and social well-being. These pro-social behaviors can act against negative social behaviors, which is a key factor in promoting the improvement of social skills in Secondary Education, where they acquire great importance for social adjustment (Zsolnai, 2002). According to Ainscow (2015), this improvement in social skills should be done through inclusive education, which should end with exclusive processes in education manifested in certain attitudes towards diversity motivated by gender, achievement, ethnicity, social class, religion, sexual orientation or disability.

From this point we start when we start processes of improvement in the school environment, for the achievement of an inclusive and quality education, defined as a project to combat school failure and against exclusion, which entails a change cultural schooling, in addition to a political commitment that goes in favor of a fairer world (Azorín, 2017).

\section{Method}

\subsection{Participants and measures}

Through a non-probabilistic sampling of an intentional nature, the instruments were applied to a total sample of 284 participants, all of them students from the University of Granada. The information was collected through two Likert questionnaires with two response options, where the number one corresponds to "Yes" and the number two corresponds to "No". 


\section{EDUCATION}

The two instruments used were the Social Skills Scale for Young Immigrants (2019) and the Cyberbullying Scale for students with cultural and religious diversity (2019). The first had 29 items, which would be reduced after its application and the second with 18, which would also be reduced, since, depending on the answers that the participants gave to the questions raised in the questionnaires, the final instrument would be formed. The study of reliability has been obtained through the internal consistency of the instrument, calculating Cronbach's Alpha $(\alpha)$ coefficient, whose result for each of the instruments was .82 for the first and .83 for the second, Results rated as excellent (León and Fernández-Díaz, 2019).

\subsection{Procedure and data analysis}

The data were collected at the University of Granada itself directly. The participants received both questionnaires and were asked to follow the instructions, which included information on the study analysis that is intended to be addressed, as well as the confidentiality and anonymity policy of the test and how to contact the researchers who supervised the project in case of doubt. For the tabulation and analysis of data, the statistical software SPSS version 24 was used. The variables used were the age and gender of the participants, and the answers to the items such as 1 "Yes" or 2 "No".

\section{Results}

Table 1

Frequencies to accept items from the Social Skills Scale for Young Immigrants.

\begin{tabular}{|c|c|c|}
\hline Ítems & $\begin{array}{l}\text { Yes } \\
(\%)\end{array}$ & $\begin{array}{l}\text { No } \\
(\%)\end{array}$ \\
\hline 1. I'm afraid they laugh at me when asking questions in class. & 80.3 & 19.7 \\
\hline 2. I have a hard time calling other Friends. & 30.3 & 69.7 \\
\hline 3. I keep my opinions to myself. & 62.7 & 37.3 \\
\hline $\begin{array}{l}\text { 4. I avoid meetings with many people for fear of doing or saying some } \\
\text { nonsense. }\end{array}$ & 70.4 & 29.6 \\
\hline 5. I find it hard to express my feelings to others. & 79.6 & 20.4 \\
\hline $\begin{array}{l}\text { 6. If I had to look for work, I'd rather write letters / emails than have to go } \\
\text { through personal interviews. }\end{array}$ & 65.5 & 34.5 \\
\hline 7. I find it hard to express my opinion in groups (classes, meetings, etc.). & 81.7 & 18.3 \\
\hline $\begin{array}{l}\text { 8. When in a store they first attend someone who entered after me, I } \\
\text { complain to the person or the clerk. }\end{array}$ & 28.2 & 71.8 \\
\hline
\end{tabular}




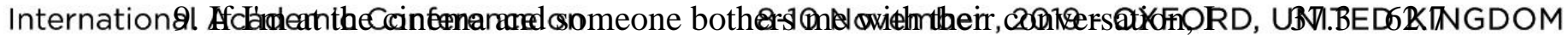
EDUCATd®Nardly tell him to shut up.

10. I am unable to ask for the price of something I am going to buy.

$38.7 \quad 61.3$

11. When someone "sneaks" in a row, I tell him that I was going first.

$43.7 \quad 56.3$

12. When a close relative bothers me, I prefer to hide my feelings rather

64.135 .9 than express anger.

13. I prefer to shut up to avoid problems with other people.

$81.0 \quad 19.0$

14. If a seller insists on showing me a product that I do not want, it is hard for me to say I do not want it.

15. When I'm in a hurry and a friend calls me on the phone, I have a hard time hanging up.

16. When I borrow my things, I lend them, even if I don't want to or don't like it. I can't say "no".

17. I don't know how to tell a friend who talks a lot to shut up.

$46.5 \quad 53.5$

18. When I decide that I don't feel like going out with a person again, I

71.128 .9 have a hard time telling them.

19. When someone calls me out, I don't know how to refuse, even if I don't 63.436 .6 feel like it.

20. I find it difficult to ask for something that I lent back.

21. If in a restaurant they do not bring me the food as I had requested, I ask $\quad \begin{array}{lll}33.8 & 66.2\end{array}$ that they do it again.

22. If I leave a store and realize that I have been wrong, I return there to ask 58.541 .5 for the right change.

23. If a friend to whom I have lent money does not return it, I remind him.

24. I have trouble asking favors from my friends. $\quad 57.742 .3$

25. When I like a boyo r a girl, I don't know what to say. $\quad 58.541 .5$

26. When I have to flatter someone, I don't know what to say.

51.448 .6

27. I'd rather shut up to avoid problems for other people. 73.926 .1

28. If I find a person that I like, I come to talk to him. $\quad 39.460 .6$ 
29. I am unable to ask someone for an appointment. $\quad 57.043 .0$

As can be seen in Table 1, items 2, 8, 9, 10, 11, 15, 17, 21 and 28 were removed from the final instrument, having a higher response coefficient in the "No" than in the "Yes".

Table 2

The cyberbullying scale for students with cultural and religious diversity.

\section{Ítems}

1. Why do they say bad words or insult me for having a different skin color

76.123 .9 through email, WhatsApp or other social networks?

2. Where can I go when they say bad words or insult me for being of a different ethnicity or religion in my school?

3. What to do when my classmates make me racist comments through social networks about my race, ethnicity or religion.

4. What to do when classmates tell me lies about my race, ethnicity or religion using the Internet, WhatsApp or social networks.

5. To whom should I turn when I feel threatened through messages in $\quad 94.45 .6$ Messenger, WhatsApp or other social networks because of my religious or ethnic tradition.

6. What should I do when someone hacks my social network account and pulls 96.53 .5 out information to create hatred towards my racial, ethnic or religious group.

7. What to do when they have hacked my account and impersonated me on Facebook, Twitter to ridicule my religious or ethnic traditions.

8. Where to go when they create a false account posing as me in order to foster 93.07 .0 fear about the customs of my country or my ethnicity or religion.

9. What to do when someone has posted personal information about my family 96.53 .5 on the internet to make fun of our traditions and customs. 
religious, ethnic or cultural traditions of my group to humiliate me.

11. What to do if I feel shame when they have posted trick photos on the 79.620 .4 internet to ridicule the religious or ethnic activity of my group and I don't know what to do.

12. What legal mechanisms should I take when they have posted trick photos on the internet to ridicule my race or culture.

\section{Who should I turn to when I have been excluded or ignored from a social} network or chat because I am from another race or belong to a religion or ethnicity other than my classmates?

14. How to denounce those who have hit me and have recorded and

disseminated the video online for being different from them. (Skin color, hair, clothing, tradition, religion).

15. What to do if they send me audios through WhatsApp to threaten me for being of a different ethnicity, religion or race

16. How do I act if they make fun of me for dressing differently from the rest?

17. What to do when they have impersonated me in a forum or social network, insulting and threatening others in order to create fear towards people of my religion or culture.

18. How can I avoid my cyber aggressors. $\quad 97.92 .1$

Looking at the results obtained in the analysis, it can be verified that none of the items, raised in the instrument, according to the criteria of the participants, are eliminated.

\section{Discussion and conclusion}

This article analyzes the need to create a mobile App for the promotion of social skills as a way out of cyberbullying situations due to intercultural reasons among the youngest. For this reason, the social and cultural conditions that are currently occurring in their misuse, and the negative consequences that are influencing them, especially in students from other cultures or religions, have been explored. (Bård Ketil Engen, 2019). 


\section{EDUCATION}

Peñalva \& Leiva (2019) define that today attention to cultural diversity is understood as a first-order challenge to strengthen equity and equality, as a guarantee of social cohesion, solidarity; as a response to the need to improve educational and social coexistence, since it is being distorted by cyberbullying. De la Garza (2019) argues that new cultural societies and advances in mobile technology have modified the habits of citizens in all facets of life. However, in several investigations they indicate that adolescents are the most vulnerable group in the problematic use of mobile phones, since they are exposed to ICT from their childhood and are provided without any previous specific training, which leads them to what is today known as cyberbullying. (Gil, et al., 2015; Berríos et al., 2015).

Cruces et al. (2016) are those who warned that the problematic use of mobile phones increases when the number of hours of use per week increases, and more specifically among adolescent students, since their frequency of use increases. In turn, students at this stage of their life tend to connect to the mobile, they feel afraid of not being connected, and of losing the experiences offered by this medium, generating a vicious circle from which it is not easy to leave, leading to misuse, such as attacking the most vulnerable groups (Beyens et al., 2016; Elhai et al., 2016). In short, its misuse contains psychophysiological, affective and relational consequences, and deteriorates personal relationships and communication with the immediate environment (Seo et al., 2016). On the other hand, Redecker (2017) emphasizes that, within the educational field, and especially in the teaching staff, it has to train students in the application of digital technologies in a critical and responsible way in terms of information, communication, content generation, welfare, problem solving and diversity. Thus, special importance is given to teacher mediation to generate interactive practices with digital technologies in order to convert their students as competent, professional and socially supportive people (Van-Deursen \& Van-Dijk, 2016).

These same arguments concern other researchers who emphasize that digital teacher competence should go beyond an individual conception of the teacher and facilitate the empowerment of their students (Castañeda, Esteve, \& Adell, 2018). It is necessary to emphasize that Bartau-Rojas, Airbe-Barandiaran \& Oregui-González (2018) defend the use of mobile phones, by itself, it is not harmful and its proper use can have beneficial effects: it favors the development of skills, offers wide possibilities of access to information and power learning. But as indicated by Della-Porta \& Diani (2015) that, by marking a misuse of these digital media, other situation are shown, where digital natives tend not to be involved in the criticism and questioning of the negative events that are being originating, even being aware of the violence suffered by other social groups. For these reasons, it has been proposed to involve university students in the creation of this APP, so that they become involved and aware of the situation that other minority groups suffer from belonging to other cultural, racial or ethnic groups. Vulnerability translates into specific human groups that, although they know what is happening around them in digital matters, because of their own social and cultural status, they are marginalized and, in that sense, away from the exercise of the right to information (Camilli-Trujillo \& Römer-Pieretti, 2017). 


\section{EDUCATION}

Therefore, in conclusion, it is necessary to create a mobile APP that serves as a means of assistance for those who, because of race, ethnicity or religion, suffer or suffer from cyberbullying, and can receive information to guide them in these types of situations.

\section{References}

Aboujaoude, E., Savage, M.W., Starcevic, V., \& Salame, W.O. (2015). Cyberbullying: Review of an old problem gone viral. Journal of Adolescent Health, 57(1), 10-18. doi: 10.1016/j.jadohealth.2015.04.011

Ainscow, M. (2015). Struggling for Equity in Education: The Legacy of Salamanca. En F. Kiuppis y R.S. Hausstätter, Inclusive education twenty years after Salamanca (41-55). New York: Peter Lang.

Azorín, C.M. (2017). Análisis de instrumentos sobre educación inclusiva y atención a la diversidad. Revista Complutense de Educación, 28(4), 1043-1060. doi: 10.5209/RCED.51343.

Bård Ketil Engen. (2019). Comprendiendo los aspectos culturales y sociales de las competencias digitales docentes. Comunicar, 27(61), 9-19. doi: 10.3916/C61-2019-01

Bartau-Rojas, I., Aierbe-Barandiaran, A., \& Oregui-González, E. (2018). Parental mediation of the Internet use of Primary students: Beliefs, strategies and difficulties. Comunicar, 54, 71-79. doi: 10.3916/C54-2018-07

Baton, E., Crosland, K. \& Haynes, R. (2019). An Evaluation of a Social Skills Application for Children Who Are Homeless. Research on Social Work Practice, 29(3), 323-332. doi: 10.1177/1049731517729038.

Berríos, L., Buxarrais, M.R., \& Garcés, M.S. (2015). Uso de las TIC y mediación parental percibida por niños de Chile. Comunicar, 45, 161-168. doi: 10.3916/C45-2015-17

Beyens, I., Frison, E., \& Eggermont, S. (2016). 'I don't want to miss a thing': Adolescents' fear of missing out and its relationship to adolescents' social needs, Facebook use, and

Facebook related stress. Computers in Human Behavior, 64, 1-8.doi: 10.1016/j.chb.2016.05.083

Boduszek, D., Debowska, A., Jonesa, A., Ma, M., Smith, D., Willmott, D., Jemmotte, E., Da Breof, H. \& Kirkmana, G. (2019). Prosocial video game as an intimate partner violence prevention tool among youth: A randomised controlled trial. Computers in Human Behavior, 93, 260-266. doi: 10.1016/j.chb.2018.12.028.

Camilli-Trujillo, C. \& Römer-Pieretti, M. (2017). Metasíntesis en alfabetización para el empoderamiento de grupos vulnerables. Comunicar, 25(53), 09-18. doi: 10.3916/C53201701

Cardozo, G., Dubini, P., \& Lorenzino, L. (2017). Bullying y ciberbullying: Un estudio comparativo con adolescentes escolarizados [Bullying and cyberbullying: A comparative study with school adolescents]. Revista Mexicana de Psicología, 34(2), 101-109. doi:

10.1016/j.pse.2016.03.002 


\section{EDUCATION}

Cartwright, L. (2017). Supporting students to use social media and comply with profesional standards. Social Work Education, 36(8), 808-892.

Castañeda, L., Esteve, F., \& Adell, J. (2018). ¿Por qué es necesario repensar la competencia docente para el mundo digital? Revista de Educación a Distancia, 56, 1-20. doi: $10.6018 / \mathrm{red} / 56 / 6$

Catalano, C. E., Luccini, A. M., \& Mortara, M. (2014). Best practices for effective design and evaluation of serious games. International Journal of Serious Games, 1(1), 1-13.

De-la-Garza, D., Peña-Ramos, J.A., \& Recuero-López, F. (2019). La participación política online de los jóvenes en México, España y Chile. Comunicar, 61(27), 83-92. doi: 10.3916/C612019-07

Della-Cioppa, V., O’Neil, A., \& Craig, W. (2015). Learning from traditional bullying interventions: A review of research on cyberbullying and best practice. Aggression and

Violent Behavior, 23, 61-68. doi: 10.1016/j.avb.2015.05.009

Della-Porta, D., \& Diani, M. (2015). Los movimientos sociales. Madrid: Centro de Investigaciones Sociológicas y Universidad Complutense de Madrid.

Elhai, J.D., Levine, J.C., Dvorak, R.D., \& Hall, B.J. (2016). Fear of missing out, need for touch, anxiety and depression arerelated to problematic smartphone use. Computer in Human Behavior, 63, 509-516. doi: 10.1016/j.chb.2016.05.079

Ellison, N., \& Vitak, J. (2015). Social Network Site Affordances and Their Relationship to Social Capital Processes. The Handbook of the Psychology of Communication Technology, 203227. Chichester, UK: John Wiley \& Sons, Ltd. doi: 10.1002/9781118426456.ch9.

Fernández, M., Mena, L. \& Riviere, J. (2010). Fracaso y abandono escolar en España. Política y Sociedad, 49(1), 197-200.

Fernández-Montalvo, J., Peñalva, A., \& Irazábal, I. (2015). Hábitos de uso y conductas de riesgo en Internet en la preadolescencia. Comunicar, 44, 113-120.

Gil, F., Del-Valle, G., Oberst, U., \& Chamarro, A. (2015). Nuevas tecnologías. ¿Nuevas patologías? El smartphone y el fear of missing out. Aloma, 33(2), 77-83.

Gil, P., Gutiérrez, E. C., \& Madrid, P. D. (2012). Incremento de las habilidades sociales a través de la expresión corporal: la experiencia en clases de iniciación al baile. Cuadernos de Psicología del Deporte, 12(2), 83-88.

González, V. \& Prendes, M. (2018). Ciberacosadores: un estudio cuantitativo con estudiantes de secundaria. Revista de Medios y Educación, 53, 137-149. doi: 10.12795/pixelbit. 2018.i53.09

Hall, W. (2016). Initial development and validation of the Bullyharm: The bullying, harassment, and aggression receipt measure. Psychology in the Schools, 53(9). doi:10.1002/pits.21957

Hosseinmardi, H., Rafiq, R. I., Han, R., Lv, Q., \& Mishra, S. (2016). Prediction of cyberbullying incidents in a media-based social network. In Proceedings of the 2016 IEEE/ACM International Conference on Advances in Social Networks Analysis and Mining, ASONAM 2016 (pp. 186-192). doi: 10.1109/ASONAM.2016.7752233.

INE (Instituto Nacional de Estadística, Statistics National Institute). 2019. Demografía y

Población. Available online: http://www.ine.es/inebmenu/mnu_migrac.htm (accessed on 7 September 2018).

Inglés, C.; Benavides, G.; Redondo, J.; García-Fernández, J. M.; Ruiz-Esteban, C., \& Estévez; C. (2009). Conducta prosocial y rendimiento académico en estudiantes españoles 


\section{EDUCATION}

de educación secundaria obligatoria. Anales De Psicología, 25(1), 93. doi:10.6018/analesps. Kim, G.M. (2016). Transcultural Digital Literacies: Cross-Border Connections and SelfRepresentations in an Online Forum. Reading Research Quarterly, 51, 199-219. doi: 10.1002/rrq.131

Lambert, A. (2016). Intimacy and Social Capital on Facebook: Beyond the Psychological

Perspective. New Media \& Society, 18(11), 2559-2575, doi: $10.1177 / 1461444815588902$.

Larrañaga, E., Navarro, R., \& Yubero, S. (2018). Factores socio-cognitivos y emocionales en la agresión del ciberacoso. Comunicar, 26(56), 19-28. doi: 10.3916/C56-2018-02

León Carrascosa, V. y Fernández-Díaz, M.J. (2019). Diseño y validación de una escala para evaluar el funcionamiento de las tutorías en Educación Secundaria. Revista de Investigación Educativa, 37(2), 525-541. doi: 10.6018/rie.37.2.345251

Montes, S.J., Guil-Bozal, R., Sánchez-Torres, N., \& Pereira-Núñez, J.A. (2016). Consumo de nuevas tecnologías y factores de personalidad en estudiantes universitarios. Revista de Comunicación y Ciudadanía Digital, 5(2), 203-228.

Nielsen, M., Haun, D., Kärtner, J., \& Legare, C. H. (2017). The persistent sampling bias in developmental psychology: A call to action. Journal of Experimental Child Psychology, 162, 31-38. doi: 10.1016/j.jecp.2017.04.017

Peñalva, A. \& Leiva, J. (2019). La interculturalidad en el contexto universitario: necesidades en la formación inicial de los futuros profesionales de la educación. Educar, 55(1), 141-158. doi: 10.5565/rev/educar.989

Redecker, C. (2017). European framework for the Digital Competence of Educators: DigCompEdu. Luxenbourg: Publications Office of the European Union. doi:

10.2760/159770

Rosen, L., Carrier, L., Miller, A., Rokkum, J., \& Ruiz, A. (2016). Sleeping with technology: Cognitive, affective, and technology usage predictors of sleep problems among college students. Sleep Health, 2, 49-56.

Sádaba, C., \& Vidales, M. (2015). El impacto de la comunicación mediada por la tecnología en el capital social: adolescentes y teléfonos móviles. Virtualis, 11(1), 75-92.

Santana-Vega, L., Gómez-Muñoz, A., \& Feliciano-García, L. (2019). Uso problemático del móvil, fobia a sentirse excluido y comunicación familiar de los adolescentes. Comunicar, 59(27), 39-47. doi:10.3916/C59-2019-04.

Seo, D.G., Park, Y., Kim, M.K., \& Park, J. (2016). Mobile phone dependency and its impacts on adolescents' social and academic behaviours. Computers in Human Behaviors, 63, 282292. doi: 10.1016/j.chb.2016.05.026

Smith, D., Ma, M., Jones, A., \& Unver, E. (2017). None in Three: The design and development of a low-cost violence prevention game for the Caribbean region. Joint international conference on serious games (pp. 259-270). Cham: Springer.

Tabuenca, B., Sánchez-Peña, J. J. \& Cuetos-Revuelta, M. J. (2019). El smartphone desde la perspectiva docente: ¿una herramienta de tutorización o un catalizador de ciberacoso? RED. Revista de Educación a Distancia, 59(01), 1-14. doi: 10.6018/red/59/01.

Tanaka, H., Sakti, S., Neubig, G. Toda, T. \& Nakamura, S. (2015). NOCOA+: Multimodal computer-based training for social and communication skills. IEICE Trans. Inf. \& Syst. 98(8), 1536-1544. doi: 10.1587/transif.2014EDP7400. 


\section{EDUCATION}

Thomée, S. (2018). Mobile Phone Use and Mental Health. A Review of the Research That Takes a Psychological Perspective on Exposure. Environmental Research and Public Health, 15, 2692; doi:10.3390/ijerph15122692.

Torrecillas-Lacave, T., Vazquez-Barrio, T., \& Monteagudo-Barandalla, L. (2017). Percepción de los padres sobre el empoderamiento digital de las familias en hogares hiperconectados. El Profesional de la Información, 26(1), 97-104. doi: 10.3145/epi.2017.ene.10.

Van-Deursen, A., \& Van-Dijk, J. (2016). Modeling traditional literacy, Internet skills and internet usage: An empirical study. Interacting with. Computers, 28(1), 13-26. doi: 10.1093/iwc/iwu027

Vidales-Bolaños, M \& Sádaba-Chalezquer, C. (2017). Adolescentes conectados: La medición del impacto del móvil en las relaciones sociales desde el capital social. Comunicar, 25(53), 19-28. doi: 10.3916/C53-2017-02.

Zsolnai, A. (2002). Relationship between children's social competence, learning, motivation and school achievement. Educational Psychology, 22, 317-329. doi:

10.1080/0144341022013854.

Zych, I., Ortega-Ruiz, R., \& Marin-Lopez, I. (2016). Cyberbullying: A systematic review of research, its prevalence and assessment issues in Spanish studies. Psicología Educativa, 22(1), 5-18. 